\title{
Development and viability of bovine embryos derived from oocytes matured and fertilized in vitro and co-cultured with bovine oviducal epithelial cells
}

\author{
K. P. Xu, B. R. Yadav*, R. W. Rorie†, L. Plante, K. J. Betteridge and \\ W. A. King \\ Department of Biomedical Sciences, University of Guelph, Guelph, Ontario, Canada N1G 2WI
}

\begin{abstract}
Summary. A co-culture system using a suspension of detached bovine oviducal epithelial cells (BOEC) has been developed as an effective culture method for supporting the development of bovine embryos derived from oocytes matured and fertilized in vitro. Four commercially available culture media (Waymouth's, Ham's F-10, TCM 199 and Ménézo's B2) supplemented with $10 \%$ oestrous cow serum, and a modified Tyrode's medium (TALP) supplemented with $0.6 \%$ bovine serum albumin were used. Ménézo's B2 resulted in the highest percentages of total uncleaved presumptive zygotes, and of the cleaved zygotes that reached at least the morula stage $(31-46 \%$ and $66-74 \%$, respectively). The embryos produced in vitro in $\mathrm{B} 2$ with BOEC resembled embryos produced in vivo with regard to numbers of cells (averaging 45.4 in morulae, 101.5 in blastocysts, 174.7 in hatching blastocysts and 195.9 in hatched blastocysts), rate of development (hatching on Day $8-9$ of culture in vitro), rate of hatching $(66 \%$ of cleaved zygotes) and pregnancy rates $(63 \%)$ resulting from the transcervical transfer of selected embryos.
\end{abstract}

Keyw'ords: oviduct cells; embryo; viability; cattle

\section{Introduction}

Methods for bovine follicular oocyte maturation and fertilization in vitro (Critser et al., 1986; Xu et al., 1987), followed by in-vitro co-culture with oviducal and cumulus cells or trophoblastic vesicles (Goto et al., 1988; Eyestone \& First, 1989; Kim et al., 1990; Fukuda et al., 1990; Iwasaki \& Nakahara, 1990; Nakao \& Nakatsuji, 1990), are now well established; but in these studies, the developmental rates of the resulting embryos were usually slower than those of normal embryos in vivo, the proportion of the embryos reaching the blastocyst stage was small, and few hatched (Marquant-Le Guienne et al., 1989). Further improvements are therefore needed if in-vitro maturation and fertilization of oocytes and in-vitro culture of the resulting embryos are to be used reliably for research and commercial purposes.

Early work by Biggers et al. (1962) showed that mouse zygotes could develop into blastocysts at the normal in-vivo rate within explanted oviducts maintained as organ cultures. The mechanism by which somatic cells promote embryonic development is obscure, although there is evidence that it involves specific factor(s) produced by the cells (Gandolfi \& Moor, 1987; Gandolfi et al., 1989). However, the number of inner-cell-mass (ICM) cells in blastocysts produced in vitro may be reduced (Marquant-Le Guienne et al., 1989), presumably reflecting deficiencies in the culture

\footnotetext{
*Present address: National Institute of Animal Genetics/National Bureau of Animal Resources, NDRI, Campus, Karnal, Haryana, 132001, India.

†Present address: Department of Animal Sciences, University of Arkansas, Fayetteville, AR 72701, USA.
} 
system. Therefore, more detailed information is needed to understand the requirements of the early embryos and the roles of the somatic cells. Data on pregnancy and calving rates obtained from the transfer of the resulting embryos are sparse.

Information on the viability of embryos produced in vitro is obviously important for the use of the technique, particularly as not all morphologically normal blastocysts are capable of giving rise to pregnancies (Whitten, 1986; Gandolfi \& Moor, 1987; Loskutoff \& Kraemer, 1990). This study examined the effects of culturing bovine embryos, derived from oocytes matured and fertilized in vitro, with bovine oviducal epithelial cells (BOEC) in various media and characterized the efficacy of the system in terms of embryo development, numbers of cells and survival after transfer to recipient animals.

\section{Materials and Methods}

Preparation of bovine oviducal epithelial cells. Oviducts from periovulatory animals (judged by the presence of a corpus haemorrhagicum, or a mature follicle in the absence of a corpus luteum, on the ovaries) were collected at a local abattoir and brought to the laboratory in phosphate-buffered saline (PBS, pH 7.4, 284 mosmol), supplemented with $2 \%$ heat-treated $\left(56^{\circ} \mathrm{C}, 30 \mathrm{~min}\right)$ fetal calf serum (FCS, Gibco, Grand Island, NY, USA) and 100 iu penicillin $/ \mathrm{ml}$ and $100 \mu \mathrm{g}$ streptomycin $/ \mathrm{ml}(\mathrm{Pen} / \mathrm{Strep}, \mathrm{Gibco})$ in an insulated container at $25^{\circ} \mathrm{C}$. For each experimental replicate, a single oviduct was dissected free from the connective tissue, and washed in Hepes-buffered tissue culture medium 199 (TCM, Gibco) supplemented with 10\% heat-treated oestrous cow serum (ECS) and Pen/Strep. The ECS was collected on the day when the animals were on standing heat and stored in aliquants at $-20^{\circ} \mathrm{C}$ until use. After cutting off the fimbrial and utero-tubal junction portions of the oviduct, the tube was squeezed with a pair of forceps to force epithelial sheets out of the lumen into a $35 \mathrm{~mm}$ Petri dish containing $3.0 \mathrm{ml}$ of medium. The sheets were aspirated and expelled a few times through a 26-gauge needle attached to a $1.0 \mathrm{ml}$ syringe to break them into smaller pieces. The resulting suspension of clumps of epithelial cells was centrifuged at $200 \mathrm{~g}$ for $2 \mathrm{~min}$, the supernatant discarded and the pellet resuspended in $4 \mathrm{ml}$ of medium. This process was repeated once. Finally, separate aliquants of $\sim 20-35 \mu l$ of the tissue in the pellet were added to $1.0 \mathrm{ml}$ volumes of Ménézo's B2 medium (B2, IMV International, Minneapolis, MN, USA) supplemented with $10 \%$ ECS, in four-well plastic dishes (Nunc, Roskilde, Denmark) and cultured overnight at $39^{\circ} \mathrm{C}$ in $5 \% \mathrm{CO}_{2}$ in air with high humidity. After $20-24 \mathrm{~h}$ of culture, BOEC clumps were collected by centrifuging at $200 \mathrm{~g}$ for $2 \mathrm{~min}$ and resuspending the pellet in $1.0 \mathrm{ml}$ of embryo culture medium after transfer to one well of a four-well culture dish. The drops for embryo co-culture were then prepared in $50 \mu \mathrm{l}$ of embryo culture medium (five media for Expt 1; B2 for Expts 2, 3 and 4) supplemented with $10 \%$ ECS under $1.0 \mathrm{ml}$ of sterile filtered $(0.22 \mu \mathrm{m}$, Millipore, Bedford, MA, USA) silicone oil in four-well dishes. From the $1.0 \mathrm{ml}$ BOEC suspension, $\sim 1.0 \mu \mathrm{l}$ of concentrated BOEC (aspirated from the bottom of the culture dish) was added to each drop and cultured again overnight under the above-mentioned conditions.

Oocyte maturation and fertilization. Ovaries, collected at the same time as the oviducts, were transported to the laboratory in warm $\left(34^{\circ} \mathrm{C}\right)$ physiological saline $(0.9 \% \mathrm{NaCl})$ in a thermos flask and washed twice in warm saline. To collect cumulus-oocyte complexes (COCs), the surfaces of the ovaries were cut finely with a razor blade, then simultaneously rinsed and tapped to release COCs into a $250 \mathrm{ml}$ beaker containing $80-100 \mathrm{ml}$ of COC collection medium, which was Ham's F-10 (F-10, Gibco) supplemented with $2 \%$ ECS or FCS, 10mm Hepes, 2 iu heparin/ml, and Pen/Strep. After every ten ovaries processed, the beaker was covered with aluminium foil and left on a warm bench $\left(30-32^{\circ} \mathrm{C}\right)$ for $5-10 \mathrm{~min}$ before pouring off three-quarters of the supernatant. The remaining COC suspension was divided between two $85 \mathrm{~mm}$ Petri dishes and searched for COCs under a dissecting microscope. Complexes with at least 2-3 compact layers of cumulus cells were selected. The procedures for in-vitro maturation and fertilization of oocytes were as previously described (Xu et al., 1987; Xu \& Greve, 1988).

Embryo culture. At 16-18 h after co-incubation of the spermatozoa and oocytes, $\sim 30$ one-cell presumptive zygotes (indistinguishable from unfertilized ova at this stage) were placed in each of the culture drops that had been prepared 18-24 h earlier. Embryo co-culture was carried out under the same conditions as for BOEC mentioned in the previous section. On the third day of co-culture, an additional $50 \mu \mathrm{l}$ of embryo culture medium was added to each drop. The total durations of the co-culture periods were 7-10 days, depending on the experiment. The developmental stages of the embryos in co-culture were determined by phase-contrast microscopy.

Experiment 1: Comparison of culture media. Five media were used for the preparation of BOEC drops. Ham's F-10 (F-10;Gibco), TCM 199 (TCM; Gibco), Waymouth's medium (WM; Gibco), and Ménézo's B2 (B2) were supplemented with $10 \%$ ECS and Pen/Strep. The fifth was a modified Tyrode's medium, supplemented with $0.6 \%$ bovine serum albumin (essentially fatty-acid-free, Sigma), lactate, pyruvate $(0.2 \mathrm{mmol} / \mathrm{l})$ and gentamycin, but without serum (TALP, Parrish et al., 1986; Greve et al., 1987). The concentrations of glucose and hypoxanthine in these media are shown in Table 1. A control group using B2 without BOEC was also included. Embryos were co-cultured for 7 days. The effects of the culture media were evaluated by the extent of embryo cleavage by Day 2 after insemination, and development up to the morula/blastocyst stages by day 7 . At least two replicates in each treatment were included in this experiment. 
Table 1. Concentrations of glucose and hypoxanthine $(\mathrm{mg} / \mathrm{l})$ in the media used in this study

\begin{tabular}{lcc}
\hline Medium & Glucose & Hypoxanthine \\
\hline $\begin{array}{l}\text { TALP } \\
\text { (modified Tyrode's medium) }\end{array}$ & 0 & 0 \\
Waymouth's medium & $5000 \cdot 00$ & 25.00 \\
(WM) & & \\
Ham's F-10 & $1100 \cdot 00$ & 4.00 \\
TCM 199 & $1000 \cdot 00$ & 0.30 \\
Ménézo's B2 & $1200 \cdot 00$ & 0 \\
\hline
\end{tabular}

Experiment 2: Observation of embryo development. As a result of Expt 1, medium B2 with BOEC was chosen for this and subsequent experiments. Two replicates were performed to follow embryonic development after exclusion of oocytes that did not cleave by Day 2, based on the assumption that most of the uncleaved oocytes were unfertilized. Embryonic developmental stages were determined by phase-contrast microscopy and recorded daily for 10 days.

Experiment 3: Determination of numbers of cells in co-cultured embryos. A total of 284 morulae and blastocysts derived from the B2 + BOEC co-culture groups in 20 replicates was used to determine numbers of cells in embryos after 7 or 8 days of culture in vitro. Each embryo was first evaluated morphologically for development and then fixed according to the method of King et al. (1979). Briefly, embryos were exposed to hypotonic sodium citrate solution $(0.88 \%, \mathrm{w} / \mathrm{v})$ for $3 \mathrm{~min}$. fixed individually on slides in methanol:acetic acid (1:1) and air-dried. Numbers of cells were determined under $\times 1000$ magnification and mitotic indices (number of metaphase nuclei/total number of nuclei) were calculated.

Experiment 4: Evaluation of embryo viability in vivo. After 7 days of culture in vitro, good or excellent quality late morulae or blastocysts were selected by morphological criteria under phase-contrast microscopy (Hasler $e t$ al., 1987). Two embryos were transferred transcervically to each of 19 recipients on Day 6 or 7 of the oestrous cycle (oestrus = Day 0). Recipients were subsequently monitored by observation for oestrus, measurement of serum progesterone concentrations on Days 21 and 24 and ultrasonic echography on Days 28 and 35. Those that did not show heat around the expected day of oestrus and had high progesterone values ( $>1.5 \mathrm{ng} / \mathrm{ml}$ ) on Days 21 and 24 , but were not pregnant at the time of echography, were classified as having extended cycles; those with a live embryo(s) (with heart beat) by echography, were classified as pregnant.

Statistical analysis. Chi-square $\left(\chi^{2}\right)$ analysis was used to compare the percentages of cleavage and formation of morulae/blastocysts. Tukey's studentized range tests (SAS package, 1988) were applied to separate means. Data were transformed to near-normality and homoscedasticity using a cubic transform and arcsine square-root transform for numbers of cells and mitotic indices at various stages, respectively (Sokal \& Rohlf, 1981).

\section{Results}

\section{Behaviour of the BOEC}

The oviducal tissue at the time of collection was in the form of sheets (Fig. 1). By the time of preparation of embryo culture drops, i.e. after overnight culture, most apparently dead cells fell from the sheets and the viable cells remained as structures resembling worms because of their appearance and active movement caused by cilia (Fig. 2). When BOEC were cultured in drops of B2, TCM or F-10 media, there was little tendency to form a monolayer in the first 3 days of culture; instead, some of the BOEC formed vesicle-like structures (Fig. 3). The viability of the BOEC was indicated by active movement of cilia, which was still clearly seen on Day 10. Some of the cells began to attach to the bottom by Day 4 or 5 , but they did not form confluent monolayers even by Day 10. In the drops of WM, there was a greater tendency to form monolayers than in B2, TCM or F-10. In the drops of TALP, however, no cells attached to the bottom of the dish, but most of the BOEC formed vesicles. Viable cells and vesicles were observed in this serum-free medium for up to 7 weeks. 


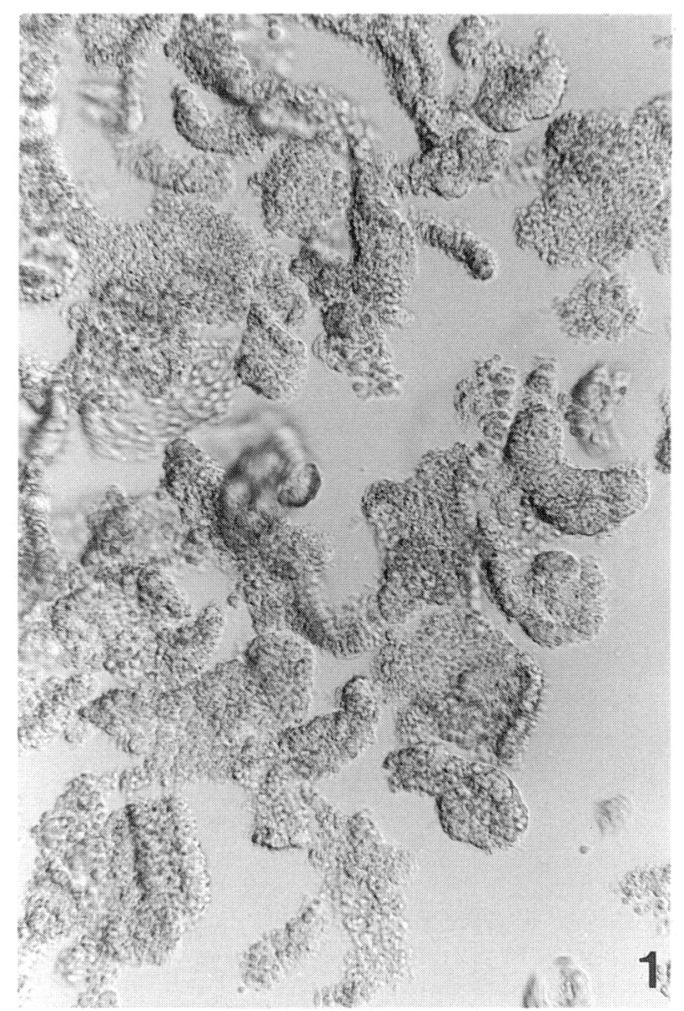

Fig. 1. Sheets of bovine oviducal epithelial cells at the time of collection $(\times 180)$.

\section{Experiment 1}

A total of 563 zygotes or oocytes was used in this experiment (Table 2). Although high cleavage rates were obtained in the TALP and WM groups, none of the embryos reached the morula/ blastocyst stage in WM and only a few did so in TALP. A high cleavage rate was also obtained in the B2 control group but, again, few embryos became morulae or blastocysts. The greatest proportion of embryos to reach the morula/blastocyst stage was achieved in B2 with BOEC, whether expressed as a percentage of the total one-cell presumptive zygotes (30.9\%) or of the cleaved zygotes $(65.9 \%)$. These rates were significantly different $(P<0.05)$ from the respective rates obtained in four of the other groups, but not from those produced in TCM.

\section{Experiment 2}

Combining the results from the two replicates, there were few ova $(7 \cdot 1 \%, 13 / 183)$ cleaved one day after spermatozoa-oocyte co-culture, but the rate increased to $62 \cdot 8 \%(115 / 183)$ by Day 2 . Thereafter, development was monitored only in those 115 cleaved embryos, as shown in Table 3. An example of some hatching blastocysts is shown in Fig. 4. Overall, 46\% (85/183) of the total one-cell presumptive zygotes or $74 \%(85 / 115)$ of the cleaved zygotes reached the morula stage or beyond.

\section{Experiment 3}

The numbers of cells and mitotic indices of the morulae, blastocysts, hatching and hatched blastocysts on Days 7 or 8 showed great variation (Table 4); on average, there were four times more 


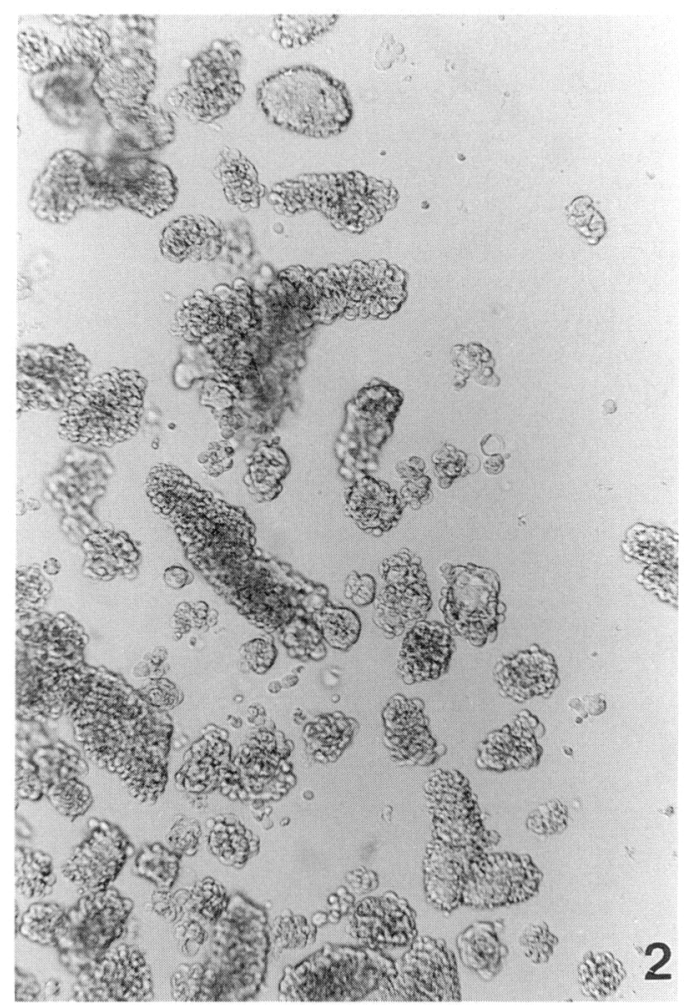

Fig. 2. Bovine oviducal epithelial cells forming worm-like structures at the time of initiation of in-vitro culture $(\times 180)$.

cells per hatched blastocyst (196) than per morula (45). Significant differences $(P<0.05)$ were seen in the average number of cells of the four embryo stages. The mitotic indices, however, decreased significantly $(P<0.05)$ from 0.071 and 0.067 for morulae and blastocysts, to 0.051 and 0.039 , respectively, when embryos reached hatching and hatched blastocyst stages.

\section{Experiment 4}

Of 19 recipients receiving embryos, $5(26.3 \%)$ returned to oestrus $20-23$ days after their previous heats, $2(10.5 \%)$ showed high progesterone values $(>1.5 \mathrm{ng} / \mathrm{ml})$ on Day 21 and returned to oestrus at Days 27 and 43, respectively, and $12(63 \%)$ were diagnosed pregnant by echography.

\section{Discussion}

Present knowledge of the requirements of embryos produced in vitro in culture is based on empirical findings. Few simple media are able to support early embryo development to the blastocyst stage (Chatot et al., 1989; Walker et al., 1989) and a variety of complex media have been used by previous investigators. In an early report by Edwards (1964) and a more recent one by Van de Sandt et al. (1990), Waymouth's medium showed some advantage over other media in culturing rabbit embryos and in maturing mouse oocytes, respectively. Ham's F-10 has been reported to be a medium of choice for the culture of bovine embryos (Wright \& Bondioli, 1981). For the culture of ovine and bovine embryos, TCM 199 has been used with some success by Gandolfi \& Moor (1987), and Eyestone \& First (1989), whereas Ménézo's B2 medium has been successfully used in human 


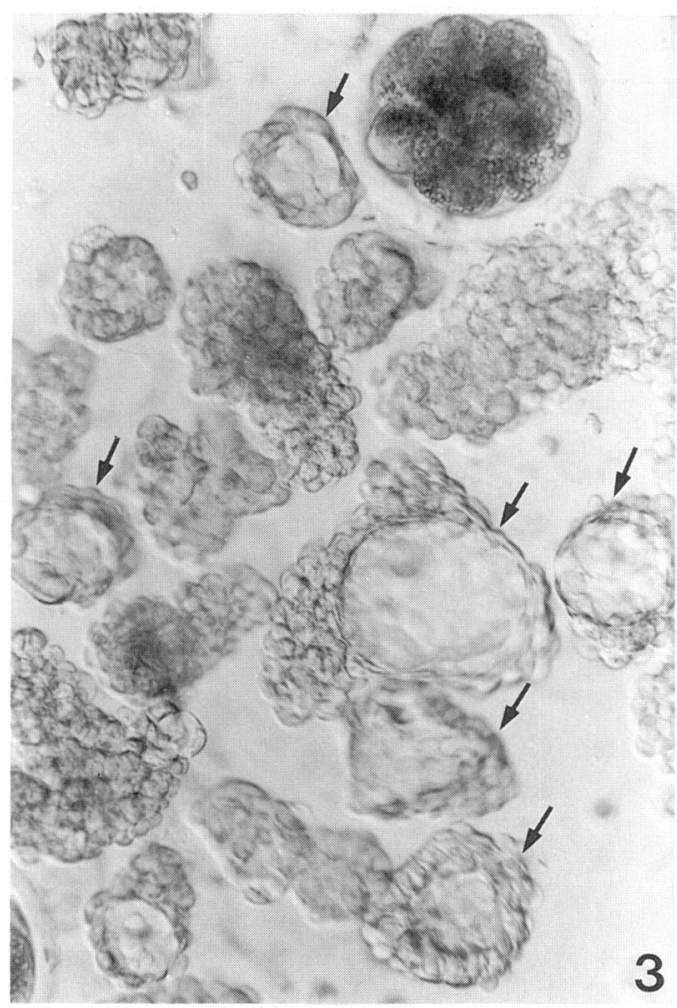

Fig. 3. Bovine oviducal epithelial cells forming vesicles (arrows) after 3 days of culture $(\times 200)$.

Table 2. Percentages of bovine embryos, produced by in-vitro fertilization, that cleaved and formed morulae/blastocysts in various culture media in the presence $(+)$ or absence ( - ) of bovine oviducal epithelial cells

\begin{tabular}{|c|c|c|c|c|c|c|}
\hline \multirow{3}{*}{$\frac{\text { Medium* }}{\text { rALP (+) }}$} & \multirow{2}{*}{\multicolumn{2}{|c|}{$\begin{array}{l}\text { Cleavage } \\
(\% \text { of total) }\end{array}$}} & \multicolumn{4}{|c|}{ Morulae/blastocysts } \\
\hline & & & \multicolumn{2}{|c|}{$\%$ of total } & \multicolumn{2}{|c|}{$\%$ of cleaved } \\
\hline & $48 \cdot 2 \pm 14 \cdot 0^{\mathrm{bc}}$ & $(41 / 85)$ & $2 \cdot 4 \pm 4 \cdot 0^{\mathrm{ab}}$ & $(2 / 85)$ & $4 \cdot 9 \pm 5 \cdot 9^{a}$ & $(2 / 41)$ \\
\hline WM(+) & $41 \cdot 9 \pm 2 \cdot 8^{b}$ & $(44 / 105)$ & $0^{a}$ & $(0 / 105)$ & - & - \\
\hline$F-10(+)$ & $19 \cdot 4 \pm 3 \cdot 7^{\mathrm{a}}$ & $(18 / 93)$ & $6 \cdot 5 \pm 2 \cdot 8^{\mathrm{bc}}$ & $(6 / 93)$ & $33 \cdot 3 \pm 11 \cdot 4^{b c}$ & $(6 / 18)$ \\
\hline $\mathrm{TCM}(+)$ & $33 \cdot 3 \pm 4 \cdot 9^{b}$ & $(31 / 93)$ & $18 \cdot 3 \pm 3 \cdot 0^{\text {cd }}$ & $(17 / 93)$ & $54 \cdot 8 \pm 5 \cdot 6^{\text {cd }}$ & $(17 / 31)$ \\
\hline B2 (+) & $46 \cdot 8 \pm 9 \cdot 5^{b c}$ & $(44 / 94)$ & $30 \cdot 9 \pm 7 \cdot 4^{\mathrm{d}}$ & $(29 / 94)$ & $65 \cdot 9 \pm 5 \cdot 6^{\mathrm{d}}$ & $(29 / 44)$ \\
\hline B2 $(-)$ & $54 \cdot 8 \pm 3 \cdot 5^{\mathrm{c}}$ & $(51 / 93)$ & $11 \cdot 8 \pm 5 \cdot 7^{\mathrm{c}}$ & $(11 / 93)$ & $21 \cdot 6 \pm 11 \cdot 1^{\mathrm{b}}$ & $(11 / 51)$ \\
\hline
\end{tabular}

Values are means \pm s.e.m.; numbers of embryos in parentheses.

*See Table I for full names of media.

a,b,c,d Values with different superscripts within a column differ significantly $(P<0.05)$ according to $\chi^{2}$ test.

in-vitro fertilization and embryo culture (Ménézo et al., 1984), and in bovine embryo culture (Marquant-Le Guienne et al., 1989). It was for these reasons that we chose the media for comparison in this study. In addition, TALP medium, used for in-vitro fertilization in this laboratory, was used as a negative control. Although direct comparison of the complex chemical compositions of these media is difficult to interpret, their concentrations of glucose and hypoxanthine are different (Table 1). This may be significant as both glucose (Schini \& Bavister, 1988) and hypoxanthine 
Table 3. Percentages of cleaved bovine embryos produced by in-vitro fertilization that reached various developmental stages after 10 successive days of co-culture with bovine oviducal epithelial cells

\begin{tabular}{|c|c|c|c|c|c|c|c|c|c|c|}
\hline \multirow[b]{2}{*}{ Stages } & \multicolumn{10}{|c|}{ Days after fertilization } \\
\hline & $1^{*}$ & 2 & 3 & 4 & 5 & 6 & 7 & 8 & 9 & 10 \\
\hline 2-cell & $7 \cdot 1$ & $19 \cdot 4$ & $13 \cdot 1$ & $5 \cdot 4$ & $5 \cdot 1$ & 5.9 & & & & \\
\hline 4-cell & & $62 \cdot 5$ & $20 \cdot 7$ & $5 \cdot 9$ & $4 \cdot 4$ & $1 \cdot 8$ & & & & \\
\hline 8-cell & & $18 \cdot 2$ & $60 \cdot 7$ & $23 \cdot 1$ & $6 \cdot 2$ & $5 \cdot 4$ & & & & \\
\hline Early morula & & & $4 \cdot 5$ & 33.9 & 34.5 & $7 \cdot 8$ & $7 \cdot 3$ & $1 \cdot 8$ & & \\
\hline Morula & & & & $26 \cdot 1$ & $33 \cdot 1$ & $17 \cdot 3$ & 3.6 & $3 \cdot 0$ & $0 \cdot 8$ & \\
\hline Blastocyst & & & & & 9.4 & 39.8 & $23 \cdot 3$ & $6 \cdot 2$ & $2 \cdot 3$ & 0.8 \\
\hline Expanded blastocyst & & & & & & $8 \cdot 8$ & $40 \cdot 1$ & $29 \cdot 7$ & $15 \cdot 1$ & $7 \cdot 3$ \\
\hline Hatching or & & & & & & & & & & \\
\hline hatched blastocyst & & & & & & & $4 \cdot 7$ & $35 \cdot 1$ & $55 \cdot 8$ & $65 \cdot 7$ \\
\hline 1-cell or degenerated & $92 \cdot 9$ & - & $1 \cdot 1$ & 5.9 & $7 \cdot 7$ & $13 \cdot 4$ & $21 \cdot 2$ & $24 \cdot 5$ & $26 \cdot 3$ & $26 \cdot 3$ \\
\hline
\end{tabular}

*Total number included on Day 1 was 183. On Day 2 and thereafter, 68 uncleaved oocytes were excluded from the calculation.

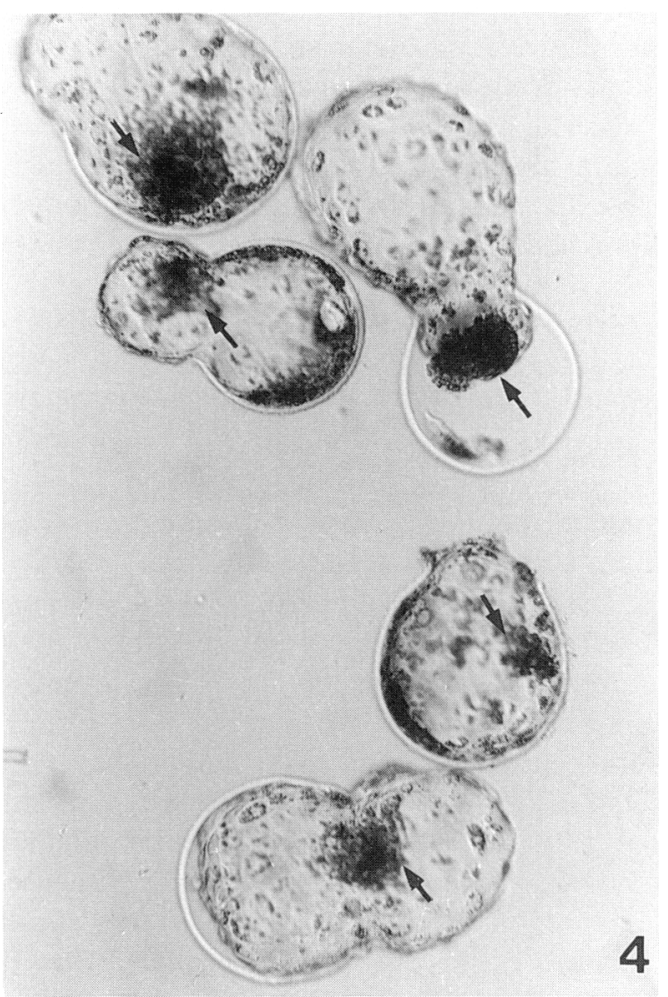

Fig. 4. Hatching blastocysts from co-culture system containing bovine oviducal epithelial cells at Day 8. Note the presence of clear inner-cell-mass cells (arrows) $(\times 180)$.

(Loutradis et al., 1987) have been implicated in 'blocks' to mouse and hamster embryo development. Using 1-2 cell bovine embryos, derived in vivo, Ellington et al. (1990a) found that, in the presence of 3.3mm glucose in medium CZB (Chatot et al., 1989), for the first 36-48 h of co-culture with oviduct cells the percentage of embryonic blastulation decreased significantly (13 vs. $31 \%$ ) 
Table 4. Numbers of cells and mitotic indices of bovine embryos produced by in-vitro fertilization and co-cultured with bovine oviducal epithelial cells

\begin{tabular}{lccc}
\hline $\begin{array}{l}\text { Stage of } \\
\text { embryo }\end{array}$ & $\begin{array}{c}\text { No. of } \\
\text { embryos }\end{array}$ & $\begin{array}{c}\text { Number of cells } \\
\text { (range) }\end{array}$ & $\begin{array}{c}\text { Mitotic indices } \\
\text { (range) }\end{array}$ \\
\hline Morula & 73 & $\begin{array}{c}45 \cdot 4 \pm 1 \cdot 17^{\mathrm{a}} \\
(32 \pm 62)\end{array}$ & $\begin{array}{c}0.071 \pm 0 \cdot 007^{\mathrm{e}} \\
(0-0 \cdot 25)\end{array}$ \\
Blastocyst & 96 & $101 \cdot 5 \pm 3 \cdot 05^{\mathrm{b}}$ & $0 \cdot 067 \pm 0 \cdot 005^{\mathrm{ef}}$ \\
& $(64-175)$ & $(0-0 \cdot 200)$ \\
Hatching blastocyst & 56 & $174.7 \pm 5 \cdot 87^{\mathrm{c}}$ & $0.051 \pm 0 \cdot 004^{\mathrm{fg}}$ \\
& & $(86-277)$ & $(0-0 \cdot 116)$ \\
Hatched blastocyst & 59 & $195 \cdot 9 \pm 7 \cdot 72^{\mathrm{d}}$ & $0 \cdot 039 \pm 0.003^{\mathrm{g}}$ \\
& & $(91 \cdot 355)$ & $(0-0 \cdot 102)$ \\
\hline
\end{tabular}

Values are means \pm s.e.m.

$a, b, c, d, e, f, g$ Values with different superscripts within a column differ significantly according to Tukey's studentized range test $(P<0.05)$.

by Day 6.5 when compared with the rate obtained in medium CZB without glucose in the initial culture period. In addition, data from Wales et al. (1987) indicated that, before Day 3 of development, glucose is not effective as an energy source for human embryos because of a block to glycolysis. In WM, which contains the highest concentrations of glucose and hypoxanthine (Table 1), no embryo passed the 16-cell stage in the present study. The highest rate of development was obtained in B2, which contains no hypoxanthine. However, hypoxanthine and glucose are not likely to be totally responsible for the poor development in WM, because low developmental rates were also obtained in TALP in which neither glucose nor hypoxanthine was present.

Somatic cells are thought to have an important role in early embryonic development and it has been hypothesized (Gandolfi \& Moor, 1987; Gandolf et al., 1989) that tissue-specific cellular factors are involved. However, the evidence for the latter is neither direct nor convincing. It has been observed that changes in the synthesis and secretion of oviducal polypeptides are associated with the oestrous cycle in cattle (Malayer et al., 1988) and sheep (Buhi et al., 1989). Indeed, the oviducal cell co-culture system has been extensively used for early embryos in domestic species, including cows (Eyestone \& First, 1989; Pollard et al., 1989; Ellington et al., 1990a, b, c), pigs (White et al., 1989), sheep (Gandolfi \& Moor, 1987), goats (Sakkas et al., 1989), and horses (Ball \& Altschul, 1990; Weber et al., 1990), as well as in humans (Sathananthan et al., 1990). Oviducal epithelial cells have also been shown to maintain the motility and fertilizing capacity of bovine spermatozoa in vitro (Pollard et al., 1991). Various other cell types including trophoblastic vesicles (Camous et al., 1984; Heyman et al., 1987), a trophoblastic cell strain (Scodras et al., 1990), cumulus cells (Goto et al., 1988), embryonic chicken cells (Blakewood et al., 1988), uterine cells (Voelkel et al., 1985; Wiemer et al., 1989), fibroblast cells (Gandolfi \& Moor, 1987), epididymal epithelial cells (J. W. Pollard, personal communication) and a transformed monkey-kidney cell line (VERO; Ménézo et al., 1990) have been used to facilitate the critical transition from maternal to embryonic control of early cleavage (Barnes \& Eyestone, 1990). This implies that any factor(s) that may exist is probably not tissue specific. However, it is also possible that different cell types could produce different beneficial factors, or different amounts of the same factor.

Various culture systems, e.g. explants (Biggers et al., 1962) and monolayers (Gandolfi \& Moor, 1987; Marquant-Le Guienne et al., 1989), as well as conditioned medium (Eyestone \& First, 1989), have been used to take advantage of the benefits of co-culture. In the present study, it appeared that the BOEC in the form of suspension in B2 drops remained viable for at least 10 days, as judged by ciliary movement, and attached to the bottom of the dish very slowly compared with the rates others have reported when using monolayers. This may have contributed to the effectiveness of 
this co-culture system, because there is evidence that some new RNAs and proteins appear after mammalian and yeast cells become quiescent (Pardee, 1989). Perhaps some of the cells in the nonproliferating BOEC clumps remain polarized and at the $\mathrm{G}_{0}$ phase of the cell cycle, and are, therefore, functionally different from rapidly proliferating monolayer cells. Factor(s) from serum also affect embryo development directly and/or through the oviduct cells since few embryos developed beyond $8-16$ cells in serum-free TALP with BOEC although the oviducal cells themselves survived in this medium for a long period.

The efficiency of a co-culture system for bovine embryos can be expressed in terms of the percentages of oocytes or embryos that cleave, pass beyond the 8-16 cell block, complete compaction, form a blastocyst, or complete hatching. The high efficiency of the BOEC co-culture system is apparent from the results of Expt 2, in which $74 \%$ of the cleaved embryos reached the blastocyst stage, $88 \%$ of these blastocysts subsequently hatching. This is much higher than in most previous reports (Eyestone \& First, 1989; Kim et al., 1990), but in contrast to the report of Marquant-Le Guienne et al. (1989) in which no embryo hatched in co-culture with an oviducal epithelial cell monolayer. Experiment 2 also showed that progressive development is comparable to that seen in vivo (Betteridge \& Fléchon, 1988), morulae occurring by Day 4, early blastocysts by Day 5, blastocysts by Day 6, expanded blastocysts by Day 7 and hatching/hatched blastocysts by Day 8. This developmental rate appears to be faster than those reported for other in-vitro systems (Eyestone \& First, 1989; Kim et al., 1990).

More cells were observed at the morula $(45 \cdot 4 \pm 1 \cdot 2)$, blastocyst $(101 \cdot 5 \pm 3 \cdot 1)$, hatching blastocyst $(174.7 \pm 5.9)$, and hatched blastocyst $(195.9 \pm 7 \cdot 7)$ stages than previously reported (Kajihara et al., 1988; Kim et al., 1990). The decreasing mitotic indices from morula to hatched blastocyst stages agrees with a previous study (Iwasaki \& Nakahara, 1990). Numbers of cells may have been underestimated, because technical difficulties can lead to cell loss during fixation and slide preparation, particularly for hatching and hatched blastocysts. However, the advantage of this fixation method is that it allows determination of the mitotic index, which reflects the viability of the embryo, as well as of the incidence of abnormal or polyploid metaphase nuclei. However, this technique does not allow determination of the number of ICM cells in the blastocysts produced in the co-culture system, although morphologically normal ICMs were seen in most of the blastocysts (Fig. 4). There are reports in mice (Whitten, 1986; Loskutoff \& Kraemer, 1990) and in sheep (Gandolfi \& Moor, 1987) that normal-looking blastocysts may not result in normal pregnancy rates when transferred. It is therefore encouraging that the limited transfer results showed that the viability of selected embryos produced in the system was comparable with that of normal embryos produced in vivo.

In conclusion, an efficient and reliable BOEC co-culture system has been established which should be useful for basic and applied studies (Seamark, 1989) as most aspects of embryo development examined were comparable to those seen in vivo. A limitation of the co-culture system at present is that it requires collection of fresh oviducts each time to set up primary BOEC culture, which is inconvenient and a source of uncontrollable variation. Methods of maintaining functionally normal cells or cell strains (Scodras et al., 1990), or of cryopreserving the cells, may overcome these problems. The mechanism of the beneficial role played by BOEC is not clear, but might be elucidated by studies using a defined medium to which known components are added (Larson et al., 1990; Rose, 1990).

The authors wish to thank D. Rieger, N. M. Loskutoff and J. W. Pollard for constructive criticism of the manuscript; R. Bériault and E. St John for their excellent technical assistance; W. Matthews-Sears, for statistical advice; the Centre d'Insémination Artificielle du Québec, St-Hyacinthe, Québec and United Breeders Incorporated, Guelph, Ontario for the semen used; and MGI Packers Inc. for the ovaries. This research was supported by NSERC Canada, Semex Canada, the Ontario Ministry of Agriculture and Food, Agriculture Canada, and the Canadian Association of Animal Breeders. 


\section{References}

Ball, B.A. \& Altschul, M. (1990) In vitro development of 4- to 8-cell equine embryos cocultured with trophoblastic vesicles or oviductal explants. Theriogenology 33, 189 (abst).

Barnes, F.L. \& Eyestone, W.H. (1990) Early cleavage and the maternal zygotic transition in bovine embryos. Theriogenology 33, 141-152.

Betteridge, K.J. \& Fléchon, J.-E. (1988) The anatomy and physiology of pre-attachment bovine embryos. Theriogenology 29, 155-187.

Biggers, J.D., Gwatkin, R.B.L. \& Brinster, R.L. (1962) Development of mouse embryos in organ culture of Fallopian tubes on a chemically defined medium. Nature, Lond. 194, 747-749.

Blakewood, E.G., Jaynes, J.M. \& Godke, R.A. (1988) Culture of pronuclear mammalian embryos using domestic chicken eggs. Theriogenology 29, 226 (abst).

Buhi, W.C., Alvarez, I.M., Mirando, M. \& Bazer, F.W. (1989) Demonstration of synthesis and secretion of oviductal polypeptides associated with estrus and E2treated ovariectomized ewes. J. Anim. Sci. 67 (Suppl. 1), 373 (abst).

Camous, S., Heyman, Y., Méziou, W. \& Ménézo, Y. (1984) Cleavage beyond the block stage and survival after transfer of early bovine embryos cultured with trophoblastic vesicles. J. Reprod. Fert. 72, 479-485.

Chatot, C. L., Ziomek, C. A., Bavister, B. D., Lewis, G. L. \& Torres, I. (1989) An improved culture medium supports development of random-bred 1-cell mouse embryos in vitro. J. Reprod. Fert. 86, 679-688.

Critser, E.S., Leibfried-Rutledge, M.L., Eyestone, W.H., Northey, D.L. \& First, N.L. (1986) Acquisition of developmental competence during maturation in vitro. Theriogenology 25, 150 (abst).

Edwards, R.G. (1964) Cleavage of one- and two-celled rabbit eggs in vitro after removal of the zona pellucida. J. Reprod. Fert. 7, 413-415.

Ellington, J.E., Carney, E.W., Farrell, P.B., Simkin, M.E. \& Foote, R.H. (1990a) Bovine 1-2-cell embryo development using a simple medium in three oviduct epithelial cell coculture systems. Biol. Reprod. 43, $97-104$.

Ellington, J.E., Farrell, P.B., Simkin, M.E., Foote, R.H., Goldman, E.E. \& McGrath, A.B. (1990b) Development and survival after transfer of cow embryos cultured from 1-2-cells to morulae or blastocysts in rabbit oviducts or in a simple medium with bovine oviduct epithelial cells. J. Reprod. Fert. 89, 293-299.

Ellington, J.E., Farrell, P.B. \& Foote, R.H. (1990c) Comparison of six-day bovine embryo development in uterine tube (oviduct) epithelial cell co-culture versus in-vivo development in the cow. Theriogenology 34, $837-844$.

Eyestone, W.H. \& First, N.L. (1989) Co-culture of early cattle embryos to the blastocyst stage with oviducal tissue or in conditioned medium. J. Reprod. Fert. 85, 715-720.

Fukuda, Y., Ichikawa, M., Naito, K. \& Toyoda, Y. (1990) Birth of normal calves resulting from bovine oocytes matured, fertilized, and cultured with cumulus cells in vitro up to the blastocyst stage. Biol. Reprod. 42, $114-119$.
Gandolfi, F. \& Moor, R. M. (1987) Stimulation of early development in sheep by co-culture with oviduct epithelial cells. J. Reprod. Fert. 81, 23-28.

Gandolfi, F., Brevini, T.A.L., Richardson, L., Brown, C.R. \& Moor, R.M. (1989) Characterization of proteins secreted by sheep oviduct epithelial cells and their function in embryonic development. Development 106, 303-312.

Goto, K., Kajihara, Y., Kosaka, S., Koba, M., Nakanishi, Y. \& Ogawa, K. (1988) Pregnancies after co-culture of cumulus cells with bovine embryos derived from in-vitro fertilization of in-vitro matured follicular oocytes. J. Reprod. Fert. 83, 753-758.

Greve, T., Xu, K.P., Callesen, H. \& Hyttel, P. (1987) Invivo development of in-vitro fertilized bovine oocytes matured in vivo and in-vitro. J. In Vitro Fert. Embryo Transfer 4, 281-285.

Hasler, J.F., McCauley, A.D., Lathrop, W.F. \& Foote, R.H. (1987) Effect of donor-embryo-recipient interactions on pregnancy rate in a large-scale bovine embryo transfer program. Theriogenology 27, 139-168.

Heyman, Y., Ménézo, Y., Chesné, P., Camous, S. \& Garnier, V. (1987) In vitro cleavage of bovine and ovine early embryos: improvement using co-culture with trophoblastic vesicles. Theriogenology 27, 59-68.

Iwasaki, S. \& Nakahara, T. (1990) Cell number and incidence of chromosomal anomalies in bovine blastocysts fertilized in vitro followed by culture in vitro or in vivo in rabbit oviducts. Theriogenology 33, 669-675.

Kajihara, Y., Goto, K., Tokumaru, M., Koba, M., Nakanishi, Y. \& Ogawa, K. (1988) Number of blastomeres and chromosome abnormalities of bovine blastocysts obtained from in-vitro matured, fertilized and cultured follicular oocytes. Jpn. J. Anim. Reprod. 34, 191-198.

Kim, C.I., Ellington, J.E. \& Foote, R.H. (1990) Maturation, fertilization and development of bovine oocytes in vitro using TCM 199 and a simple defined medium with co-culture. Theriogenology 33, 433-440.

King, W.A., Linares, T., Gustavsson, I. \& Bane, A. (1979) A method for preparation of chromosomes from bovine zygotes and blastocysts. Vet. Sci. Commun. 3, $51-56$.

Larson, R.C., Ignotz, G.G. \& Currie, W.B. (1990) Defined medium containing TGF $\beta$ and bFGF permits development of bovine embryos beyond the '8-cell block'. J. Reprod. Fert. Abst Ser. 5, 16 (abst).

Loskutoff, N.M. \& Kraemer, D.C. (1990) Intraspecific blastocyst reconstitution in mice using giant trophectodermal vesicles produced by multiple embryo aggregation. Biol. Reprod. 43, 1037-1044.

Loutradis, D., John, D. \& Kiessling, A.A. (1987) Hypoxanthine causes a 2-cell block in random-bred mouse embryos. Biol. Reprod. 37, 311-316.

Malayer, J.R., Hansen, P.J. \& Buhi, W.C. (1988) Secretion of proteins by cultured bovine oviducts collected from estrus through early diestrus. J. exp. Zool. 248, 345-353.

Marquant-Le Guienne, B., Gérard, M., Solari, A. \& Thibault, C. (1989) In-vitro culture of bovine egg fertilized either in vivo or in vitro. Reprod. Nutr. Dev. 29, $559-568$. 
Ménézo, Y., Testart, J. \& Perrone, D. (1984) Serum is not necessary in human in-vitro fertilization, early embryo culture, and transfer. Fert. Steril. 42, 750-755.

Ménézo, Y.J.R., Guérin, J.-F. \& Czyba, J.-C. (1990) Improvement of human early embryo development in vitro by coculture on monolayers of Vero cells. Biol. Reprod. 42, 301-306.

Nakao, H. \& Nakatsuji, N. (1990) Effects of co-culture, medium components and gas phase on in vitro culture of in-vitro matured and in-vitro fertilized bovine embryos. Theriogenology 33, 591-600.

Pardee, A.B. (1989) $G_{1}$ events and regulation of cell proliferation. Science, $N Y$ 246, 603-608.

Parrish, J.J., Susko-Parrish, J.L., Leibfried-Rutledge, M.L., Critser, E.S., Eyestone, W.H. \& First, N.L. (1986) Bovine in vitro fertilization with frozenthawed semen. Theriogenology 25, 591-600.

Pollard, J.W., Xu, K.P., Rorie, R.W., King, W.A. \& Betteridge, K.J. (1989) Influence of various oviductal epithelial cell culture systems on the development of early cleavage stage bovine embryos in vitro. Theriogenology 31, 239 (abst).

Pollard, J.W., Plante, C., King, W.A., Hansen, P.J., Betteridge, K.J. \& Suarez, S.S. (1991) Fertilizing capacity of bovine sperm may be maintained by binding to oviductal epithelial cells. Biol. Reprod. 44, 102107.

Rose, T.A. (1990) Bovine morula/blastocyst development in vitro in simple medium. Biol. Reprod. $\mathbf{4 2}$ (Suppl. 1), 58 (abst).

Sakkas, D., Batt, P.A. \& Cameron, A.W.N. (1989) Development of preimplantation goat (Capra hircus) embryos in vivo and in vitro. J. Reprod. Fert. 87, $359-365$.

Sathananthan, H., Bongso, A., Ng, S.-C., Ho, J., Mok, H. \& Ratnam, S. (1990) Ultrastructure of preimplantation human embryos co-cultured with human ampullary cells. Hum. Reprod. 5, 309-318.

SAS Institute Inc. (1988) SAS/STAT(IM) User's Guide, Release 6.03 Edn. SAS Institute Inc., Cary, NC.

Schini, S.A. \& Bavister, B.D. (1988) Two-cell block to development of cultured hamster embryos is caused by phosphate and glucose. Biol. Reprod. 39, 1183-1192.

Scodras, J.M., Pollard, J.W., Plante, L. \& Betteridge, K.J. (1990) Establishment of a bovine trophoblast cell line supporting the development of in vitro matured and fertilized oocytes. Biol. Reprod. 42 (Suppl. 1), 167 (abst).
Seamark, R.F. (1989) Transgenesis: the challenge for the reproductive biologist. Reprod. Fert. Dev. 1, 391-395.

Sokal, R.R. \& Rohlf, F.J. (1981) Section 13.9 FF. In Biometry The Principles and Practice of Statistics in Biological Research, p. 859. W.H. Freeman, San Francisco.

Van de Sandt, J.J.M., Schroeder, A.C. \& Eppig, J.J. (1990) Culture media for mouse oocyte maturation affect subsequent embryonic development. Mol. Reprod. Dev. 25, 164-171.

Voelkel, S.A., Amborski, G.F., Hill, K.G. \& Godke, R.A. (1985) Use of a uterine-cell monolayer culture system for micromanipulated bovine embryos. Theriogeno$\log y$ 24, 271-281.

Wales, R.G., Whittingham, D.G., Hardy, K. \& Craft, I.L. (1987) Metabolism of glucose by human embryos. $J$. Reprod. Fert. 79, 289-297.

Walker, S.K., Lampe, R.J. \& Seamark, R.F. (1989) Culture of sheep zygotes in synthetic oviduct fluid medium with different concentrations of sodium bicarbonate and Hepes. Theriogenology 32, 797-804.

Weber, J.A., Freeman, D.A., Vanderwall, D.K. \& Woods, G.L. (1990) Coculture of day-2 equine embryos with oviductal or uterine tissue. Theriogenology 33, 344 (abst).

White, K.L., Hehnke, K., Rickords, L.F., Southern, L.L., Thompson, Jr, D.L. \& Wood, T.C. (1989) Early embryonic development in vitro by coculture with oviductal epithelial cells in pigs. Biol. Reprod. 41, $425-430$.

Whitten, W.K. (1986) Should expansion and hatching of mouse blastocysts in culture be used to evaluate media for human IVF and embryo culture? Biol. Reprod. 34 (Suppl. 1), 229 (abst).

Wiemer, K.E., Malter, H.E., Cohen, J., Wright, G., Wiker, S.R. \& Godke, R.A. (1989) Coculture of human zygotes on fetal bovine uterine fibroblasts: embryonic morphology and implantation. Fert. Steril. 52, 503-508.

Wright, Jr, R.W. \& Bondioli, K.R. (1981) Aspects of invitro fertilization and embryo culture in domestic animals. J. Anim. Sci. 53, 702-729.

Xu, K.P. \& Greve, T. (1988) A detailed analysis of early events during in-vitro fertilization of bovine follicular oocytes. J. Reprod. Fert. 82, 127-134.

Xu, K.P., Greve, T., Callesen, H. \& Hyttel, P. (1987) Pregnancy resulting from cattle oocytes matured and fertilized in vitro. J. Reprod. Fert. 81, 501-504.

Received 21 August 1990 